\title{
Evidence for the Necessity to Systematically Assess Micronutrient Status Prior to Bariatric Surgery
}

\author{
Barbara Ernst - Martin Thurnheer • \\ Sebastian M. Schmid • Bernd Schultes
}

Received: 26 February 2008 / Accepted: 16 April 2008 / Published online: 20 May 2008

(C) Springer Science + Business Media, LLC 2008

\begin{abstract}
Background Bariatric surgery has been proven the most effective treatment of morbid obesity, but micronutrient deficiency following bariatric surgery is a major concern. Increasing evidence points to a generally poor micronutrient status in obese subjects.

Methods We assessed micronutrient status in 232 morbidly obese subjects $\left(\mathrm{BMI} \geq 35 \mathrm{~kg} / \mathrm{m}^{2}\right)$ prior to bariatric surgery. Serum albumin, calcium, phosphate, magnesium, ferritin, hemoglobin, zinc, folate, vitamin $\mathrm{B}_{12}, 25-\mathrm{OH}$ vitamin $\mathrm{D}_{3}$, and intact parathormone (iPTH) were determined. In a subsample of 89 subjects, we additionally assessed copper, selenium, vitamin $\mathrm{B}_{1}, \mathrm{~B}_{3}, \mathrm{~B}_{6}, \mathrm{~A}$, and $\mathrm{E}$ levels.

Results Deficiencies were found in $12.5 \%$ of the subjects for albumin, $8.0 \%$ for phosphate, $4.7 \%$ for magnesium, $6.9 \%$ for ferritin, $6.9 \%$ for hemoglobin, $24.6 \%$ for zinc, $3.4 \%$ for folate, and $18.1 \%$ for vitamin $\mathrm{B}_{12}$. In addition, $25.4 \%$ showed a severe $25-\mathrm{OH}$ vitamin $\mathrm{D}_{3}$ deficiency, which was accompanied by a secondary hyperparathyroidism in $36.6 \%$ cases. Prevalence of albumin deficiency $(p<0.007)$ and of anemia $(p<0.003$; in women only) significantly increased with BMI. Of note, $48.7 \%$ of the subjects showed at least one of the most prevalent deficiencies, i.e., vitamin $\mathrm{B}_{12}$,
\end{abstract}

The authors have no commercial interest to disclose. The study was financially supported by a grant from Johnson \& Johnson. The funder had no role in the study design, analysis and publication of the data.

B. Ernst $\cdot$ M. Thurnheer $\cdot$ B. Schultes $(\bowtie)$

Interdisciplinary Obesity Center, Kantonsspital St. Gallen,

CH-9400 Rorschach, Switzerland

e-mail: bernd.schultes@kssg.ch

S. M. Schmid • B. Schultes

Department of Internal Medicine I, University of Luebeck,

23538 Luebeck, Germany zinc and severe $25-\mathrm{OH}$ vitamin $\mathrm{D}_{3}$ deficiency. In the subsample, $32.6 \%$ showed a selenium, $5.6 \%$ a vitamin $B_{3}$, $2.2 \%$ a vitamin $\mathrm{B}_{6}$, and $2.2 \%$ a vitamin $\mathrm{E}$ deficiency. Copper, vitamin $B_{1}$, and vitamin $A$ deficiency was found in none of the subjects.

Conclusion Data indicate a high prevalence of micronutrient deficiencies in morbidly obese subjects. Based on these results, we strongly recommend a systematic assessment of the micronutrient status in all candidates for bariatric surgery.

Keywords Morbid obesity · Micronutrient deficiencies . Preoperative assessment

\section{Introduction}

Bariatric surgery has been proven the most effective treatment of morbid obesity leading not only to a longterm weight reduction $[1,2]$ but also to a significant improvement of health-related quality of life [3] and a reduction of overall mortality $[4,5]$. However, micronutrient deficiency after bariatric procedures is a major concern $[6,7]$, which may prevent a physician recommending morbid obese patients for this effective treatment.

Positive energy balance deriving from excessive food intake in relation to energy expenditure is the pathophysiological basis of obesity in most cases, but the quality of ingested foods might be poor [8]. Here, the question arises as to whether in obese subjects micronutrient supply from consumed foods is sufficient to cover their organism's demands. Surprisingly, a quite low number of studies, most of which are summarized in Table 1, have been carried out to address this question. Data from the NHANES III including 3,831 obese subjects indicated a higher likelihood 


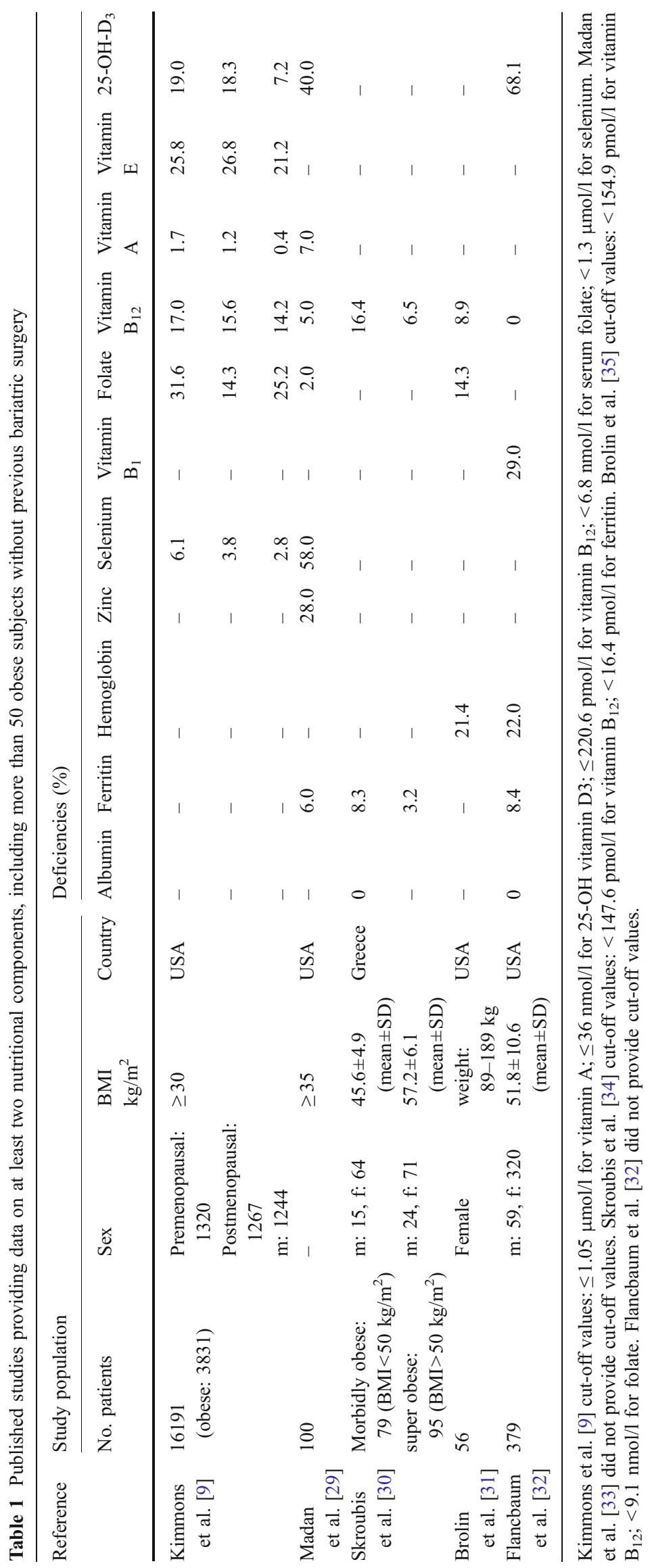


of deficiencies in multiple micronutrient components in subjects with a BMI above $30 \mathrm{~kg} / \mathrm{m}^{2}$ as compared with normal-weight subjects [9]. However, data from that study do not clarify the question whether the likelihood of micronutrient deficiencies increases with the severity of obesity, i.e., with increasing BMI classes. Also, the majority of studies focusing on morbid obesity (BMI $\geq$ $35 \mathrm{~kg} / \mathrm{m}^{2}$ ) only assessed a limited number of micronutrient components prior to bariatric procedures. For instance, concentrations of vitamin $\mathrm{B}_{3}, \mathrm{~B}_{6}$, and copper, deficiencies of which have in part been attributed to bariatric operations [10-22], have not yet been systematically studied in candidates for bariatric surgery prior to the operation.

From the clinical point of view, knowing the prevalence of micronutrient deficiencies in morbidly obese patients appears to be of utmost importance. Otherwise, deficiencies detected after bariatric surgery cannot unequivocally be attributed to the surgical intervention. Here, we report results of a comprehensive micronutrient assessment in 232 morbidly obese subjects $\left(\mathrm{BMI} \geq 35 \mathrm{~kg} / \mathrm{m}^{2}\right)$ who were evaluated for bariatric surgery in our Interdisciplinary Obesity Center.

\section{Methods}

In this prospective study, we assessed a comprehensive micronutrient status in all patients with a BMI of $35 \mathrm{~kg} / \mathrm{m}^{2}$ or higher who were referred by their general practitioner or by themselves to our Interdisciplinary Obesity Center for evaluation for bariatric surgery between November 2005 and December 2007. Patients who had undergone a bariatric procedure, e.g., gastric banding, prior to the present assessment were excluded from the study. Also, patients with overt renal function impairment (serum creatinine concentration $>120 \mu \mathrm{mol} / \mathrm{l}$ for men, $>100 \mu \mathrm{mol} / 1$ for women) were excluded from the study, since impaired renal function is well known to significantly affect vitamin D metabolism and thereby, PTH levels and calcium homeostasis. All the patients underwent an extensive endocrinological examination in order to detect endocrine disorders potentially responsible for their obesity, e.g., untreated hypothyroidism. However, such an endocrine disorder was detected in none of the subjects. The final sample included 232 patients. Informed consent was obtained from all the patients.

Height and weight were measured with patients wearing light clothing but no shoes. BMI was defined as weight $(\mathrm{kg})$ divided by height squared $\left(\mathrm{m}^{2}\right)$. In all the patients, blood samples were drawn in the morning (8:00-11:00) after an overnight fast. Micronutrient deficiency was defined as follows: serum albumin $<536.0 \mu \mathrm{mol} / \mathrm{l}$, serum calcium $<2.0 \mathrm{mmol} / \mathrm{l}$, serum phosphate $<0.8 \mathrm{mmol} / 1$, serum magne- sium $<0.7 \mathrm{mmol} / 1$, serum ferritin $<18.0 \mathrm{pmol} / \mathrm{l}$, hemoglobin $<8.7 \mathrm{mmol} / 1$ for men and $<7.5 \mathrm{mmol} / 1$ for women, serum zinc $<11.0 \mu \mathrm{mol} / 1$, serum copper $<13.0 \mu \mathrm{mol} / 1$, serum selenium $<0.9 \mu \mathrm{mol} / \mathrm{l}$, serum vitamin $\mathrm{B}_{1}<933.0 \mathrm{nmol} / \mathrm{l}$, serum vitamin $B_{3}<65.0 \mu \mathrm{mol} / 1$, serum vitamin $B_{6}<33.2$ $\mathrm{nmol} / \mathrm{l}$, serum folate $<4.5 \mathrm{nmol} / 1$, serum vitamin $\mathrm{B}_{12}<133.0$ $\mathrm{pmol} / \mathrm{l}$, serum vitamin $\mathrm{A}<0.7 \mu \mathrm{mol} / \mathrm{l}$, serum vitamin $\mathrm{E}$ $<12.0 \mu \mathrm{mol} / \mathrm{l}$, serum $25-\mathrm{OH}$ vitamin $\mathrm{D}_{3}<76.0 \mathrm{nmol} / \mathrm{l}$ (mild deficiency), $<50.0 \mathrm{nmol} / 1$ (moderate deficiency), and $<25.0$ $\mathrm{nmol} / \mathrm{l}$ (severe deficiency). Serum iPTH $>6.5 \mathrm{pmol} / 1$ indicated hyperparathyroidism.

Serum copper, selenium, vitamin $\mathrm{B}_{1}, \mathrm{~B}_{3}, \mathrm{~B}_{6}, \mathrm{~A}$, and $\mathrm{E}$ were only assessed in a sub-sample of 89 patients. In all patients with vitamin $B_{12}$ deficiency, antibodies against parietal cells were measured to exclude atrophic gastritis. However, increased antibody titers could not be detected in any of the subjects tested.

Data were analyzed by using SPSS 12.1 for Windows (SPSS, Chicago, IL, USA). To assess the influence of the degree of obesity, the subjects were grouped according to their BMI in four groups, i.e., BMI $35-<40 \mathrm{~kg} / \mathrm{m}^{2}$, BMI $40-<45 \mathrm{~kg} / \mathrm{m}^{2}$, BMI $45-<50 \mathrm{~kg} / \mathrm{m}^{2}$ and BMI $>50 \mathrm{~kg} / \mathrm{m}^{2}$. Unless otherwise indicated, data are reported as mean \pm SD. Variables were compared between different BMI groups by $\chi^{2}$ test for discrete variables and ANOVA for continuous variables. For pairwise comparisons, Student's $t$ test or $\chi^{2}$ test was used. Associations between micronutrient levels and BMI were evaluated by Pearson's correlation coefficient. A $p$ value $<0.05$ was considered significant.

\section{Results}

The clinical characteristics of the study population are presented in Table 2. There were no significant differences in age and height across the four different BMI groups. Interestingly, the number of evaluated men was higher in the BMI $>40 \mathrm{~kg} / \mathrm{m}^{2}$ groups than in the BMI $35-40 \mathrm{~kg} / \mathrm{m}^{2}$ group (all $p<0.05$ for pairwise comparisons).

Table 3 provides data on micronutrients measured in the entire study population. Overall, below cut-off levels, i.e., deficiencies, were found in $12.5 \%$ of the subjects for albumin, $8.0 \%$ for phosphate, $4.7 \%$ for magnesium, $6.9 \%$ for ferritin, $6.9 \%$ for hemoglobin $(<8.7 \mathrm{mmol} / \mathrm{l}$ in men and $<7.5 \mathrm{mmol} / 1$ in women), $24.6 \%$ for zinc, $3.4 \%$ for folate, $18.1 \%$ for vitamin $\mathrm{B}_{12}$, and $89.7 \%$ for $25-\mathrm{OH}$ vitamin $\mathrm{D}_{3}$ ( $<76 \mathrm{nmol} / \mathrm{l}$ ). In addition, $61.2 \%$ of the patients not only showed a mild but a moderate $(<50 \mathrm{nmol} / \mathrm{l})$ and $25.4 \%$ even a severe $(<25 \mathrm{nmol} / \mathrm{l}) \quad 25-\mathrm{OH}$ vitamin $\mathrm{D}_{3}$ deficiency. According to the high prevalence of $25-\mathrm{OH}$ vitamin $\mathrm{D}_{3}$ deficiency, $36.6 \%$ of the patients showed a secondary hyperparathyroidism with iPTH levels above $6.5 \mathrm{pmol} / \mathrm{l}$. A primary hyperparathyroidism could be excluded in all the 
Table 2 Clinical characteristics of the study population

\begin{tabular}{lccccc}
\hline & Total $(n=232)$ & BMI $\left(\mathrm{kg} / \mathrm{m}^{2}\right)$ & & \\
\cline { 3 - 6 } & & $35-<40(n=47)$ & $40-<45(n=87)$ & $45-<50(n=56)$ & $>50(n=42)$ \\
\hline Women (\%) & 71.1 & 85.1 & $67.8^{*}$ & $67.9^{*}$ & $66.7^{*}$ \\
Age (y) & $40.5 \pm 11.6$ & $40.0 \pm 11.3$ & $38.9 \pm 11.3$ & $42.0 \pm 11.3$ & $42.1 \pm 12.8$ \\
Height $(\mathrm{cm})$ & $166.2 \pm 8.7$ & $166.0 \pm 7.3$ & $166.6 \pm 8.8$ & $166.3 \pm 9.2$ & 0.131 \\
Weight $(\mathrm{kg})$ & $124.3 \pm 20.7$ & $104.5 \pm 9.1$ & $117.5 \pm 13.1$ & $131.6 \pm 14.8$ & $165.7 \pm 9.3$ \\
BMI $\left(\mathrm{kg} / \mathrm{m}^{2}\right)$ & $44.9 \pm 6.2$ & $37.9 \pm 1.4$ & $42.2 \pm 1.4$ & $47.5 \pm 1.5$ & 0.952 \\
\end{tabular}

Data are the mean $\pm \mathrm{SD}$, or percentage. $P$ values derive from $\chi^{2}$ test or ANOVA as appropriate.

$* P<0.05$ vs. BMI group $35-<40$ by $\chi^{2}$ test.

patients since none of them showed an increased serum calcium level.

Analyzing data separately for BMI categories revealed a significant difference in the prevalence of albumin deficiency ( $p=0.007$ ) and hemoglobin deficiency ( $p=0.003$; in women) between groups with higher rates of deficiencies with increasing BMI.
Figure 1 illustrates the distribution of the three most prevalent deficiencies, i.e., $25-\mathrm{OH}$ vitamin $\mathrm{D}_{3}(<25 \mathrm{nmol} / \mathrm{l})$, vitamin $\mathrm{B}_{12}$, and zinc deficiencies. Subnormal serum values of at least one parameter were found in $48.7 \%$ of the patients (Fig. 1a). When elevated iPTH levels instead of $25-\mathrm{OH}$ vitamin $\mathrm{D}_{3}(<25 \mathrm{nmol} / \mathrm{l})$ were used as an indicator of $25-\mathrm{OH}$ vitamin $\mathrm{D}_{3}$ deficiency, the number of patients

Table 3 Absolute values and rates of prevalence of deficiency in micronutrients

\begin{tabular}{|c|c|c|c|c|c|c|}
\hline & \multirow[t]{2}{*}{ Total $(n=232)$} & \multicolumn{4}{|l|}{ BMI } & \multirow[t]{2}{*}{$P($ trend $)$} \\
\hline & & $35-<40(n=47)$ & $40-<45(n=87)$ & $45-<50(n=56)$ & $>50(n=42)$ & \\
\hline \multicolumn{7}{|l|}{ Absolute values } \\
\hline Albumin $(\mu \mathrm{mol} / \mathrm{l})$ & $612.9 \pm 65.2$ & $637.6 \pm 66.7$ & $626.0 \pm 66.7$ & $597.0 \pm 46.4$ & $581.0 \pm 66.7$ & $<0.001$ \\
\hline Total calcium $(\mathrm{mmol} / \mathrm{l})$ & $2.3 \pm 0.1$ & $2.3 \pm 0.1$ & $2.3 \pm 0.1$ & $2.2 \pm 0.1$ & $2.2 \pm 0.1$ & 0.045 \\
\hline Phosphate $(\mathrm{mmol} / \mathrm{l})^{\mathrm{a}}$ & $1.0 \pm 0.2$ & $1.0 \pm 0.2$ & $1.0 \pm 0.2$ & $1.0 \pm 0.2$ & $1.0 \pm 0.2$ & 0.993 \\
\hline Magnesium $(\mathrm{mmol} / \mathrm{l})^{\mathrm{b}}$ & $0.9 \pm 0.1$ & $0.9 \pm 0.9$ & $0.9 \pm 0.1$ & $0.9 \pm 0.2$ & $0.8 \pm 0.1$ & 0.708 \\
\hline Ferritin $(\mathrm{pmol} / \mathrm{l})$ & $165.2 \pm 163.8$ & $132.5 \pm 122.0$ & $171.1 \pm 169.4$ & $200.5 \pm 193.4$ & $142.4 \pm 143.1$ & 0.145 \\
\hline Hemoglobin $(\mathrm{mmol} / \mathrm{l})$ & $8.9 \pm 0.9$ & $8.9 \pm 0.8$ & $9.1 \pm 0.7$ & $8.8 \pm 0.9$ & $8.7 \pm 1.1$ & 0.123 \\
\hline Zinc $(\mu \mathrm{mol} / \mathrm{l})$ & $12.2 \pm 1.8$ & $12.3 \pm 1.6$ & $12.4 \pm 1.9$ & $12.2 \pm 1.6$ & $11.9 \pm 1.8$ & 0.458 \\
\hline Folate $(\mathrm{nmol} / \mathrm{l})$ & $13.1 \pm 8.4$ & $11.3 \pm 4.8$ & $13.6 \pm 8.6$ & $14.7 \pm 11.3$ & $12.0 \pm 6.8$ & 0.170 \\
\hline Vitamin $B_{12}(\mathrm{pmol} / \mathrm{l})$ & $202.2 \pm 81.9$ & $192.6 \pm 73.1$ & $206.5 \pm 78.4$ & $218.0 \pm 94.4$ & $182.5 \pm 78.1$ & 0.144 \\
\hline 25-OH-D3 (nmol/l) & $47.0 \pm 36.4$ & $50.3 \pm 28.2$ & $51.1 \pm 49.3$ & $44.5 \pm 24.5$ & $38.2 \pm 23.1$ & 0.241 \\
\hline IPTH (pmol/l) & $6.2 \pm 2.9$ & $5.4 \pm 2.1$ & $5.9 \pm 2.5$ & $6.7 \pm 3.9$ & $6.9 \pm 2.8$ & 0.046 \\
\hline \multicolumn{7}{|l|}{ Deficiencies $(\%)$} \\
\hline Albumin $<536.0 \mu \mathrm{mol} / 1$ & 12.5 & 8.5 & 9.2 & 8.9 & 28.6 & 0.007 \\
\hline Phosphate $<0.8 \mathrm{mmol} / \mathrm{l}^{\mathrm{a}}$ & 8.0 & 12.8 & 7.2 & 5.5 & 7.7 & 0.573 \\
\hline Magnesium $<0.7 \mathrm{mmol} / \mathrm{l}^{\mathrm{b}}$ & 4.7 & 4.5 & 0 & 10.0 & 7.5 & 0.052 \\
\hline Ferritin $<18.0 \mathrm{pmol} / 1$ & 6.9 & 10.6 & 4.6 & 5.4 & 9.5 & 0.494 \\
\hline Hemoglobin $<8.7 \mathrm{mmol} / \mathrm{l}^{\mathrm{c}}$ & 10.1 & 15.4 & 3.0 & 17.4 & 10.0 & 0.313 \\
\hline Hemoglobin $<7.5 \mathrm{mmol} / \mathrm{l}^{\mathrm{d}}$ & 5.9 & 2.0 & 1.4 & 8.0 & 18.8 & 0.003 \\
\hline Zinc $<11.0 \mu \mathrm{mol} / 1$ & 24.6 & 25.5 & 23.0 & 17.9 & 35.7 & 0.229 \\
\hline Folate $<4.5 \mathrm{nmol} / 1$ & 3.4 & 0 & 3.4 & 5.4 & 4.8 & 0.474 \\
\hline Vitamin $\mathrm{B}_{12}<133.0 \mathrm{pmol} / 1$ & 18.1 & 17.0 & 16.1 & 16.1 & 26.2 & 0.516 \\
\hline $25-\mathrm{OH}-\mathrm{D}<76.0 \mathrm{nmol} / 1$ & 89.7 & 85.1 & 89.7 & 89.3 & 95.2 & 0.481 \\
\hline $25-\mathrm{OH}-\mathrm{D}<50.0 \mathrm{nmol} / 1$ & 61.2 & 53.2 & 58.6 & 60.7 & 76.2 & 0.139 \\
\hline $25-\mathrm{OH}-\mathrm{D}<25.0 \mathrm{nmol} / 1$ & 25.4 & 23.4 & 20.7 & 26.8 & 35.7 & 0.317 \\
\hline $\mathrm{IPTH}>6.5 \mathrm{pmol} / 1$ & 36.6 & 25.5 & 36.8 & 42.9 & 40.5 & 0.296 \\
\hline
\end{tabular}

Data are the mean $\pm \mathrm{SD}$, or percentage. $P$ values derive from $\chi^{2}$ test or ANOVA as appropriate.

${ }^{\text {a }}$ Measured in 224 patients.

${ }^{\mathrm{b}}$ Measured in 213 patients.

${ }^{\mathrm{c}}$ For men.

${ }^{\mathrm{d}}$ For women. 

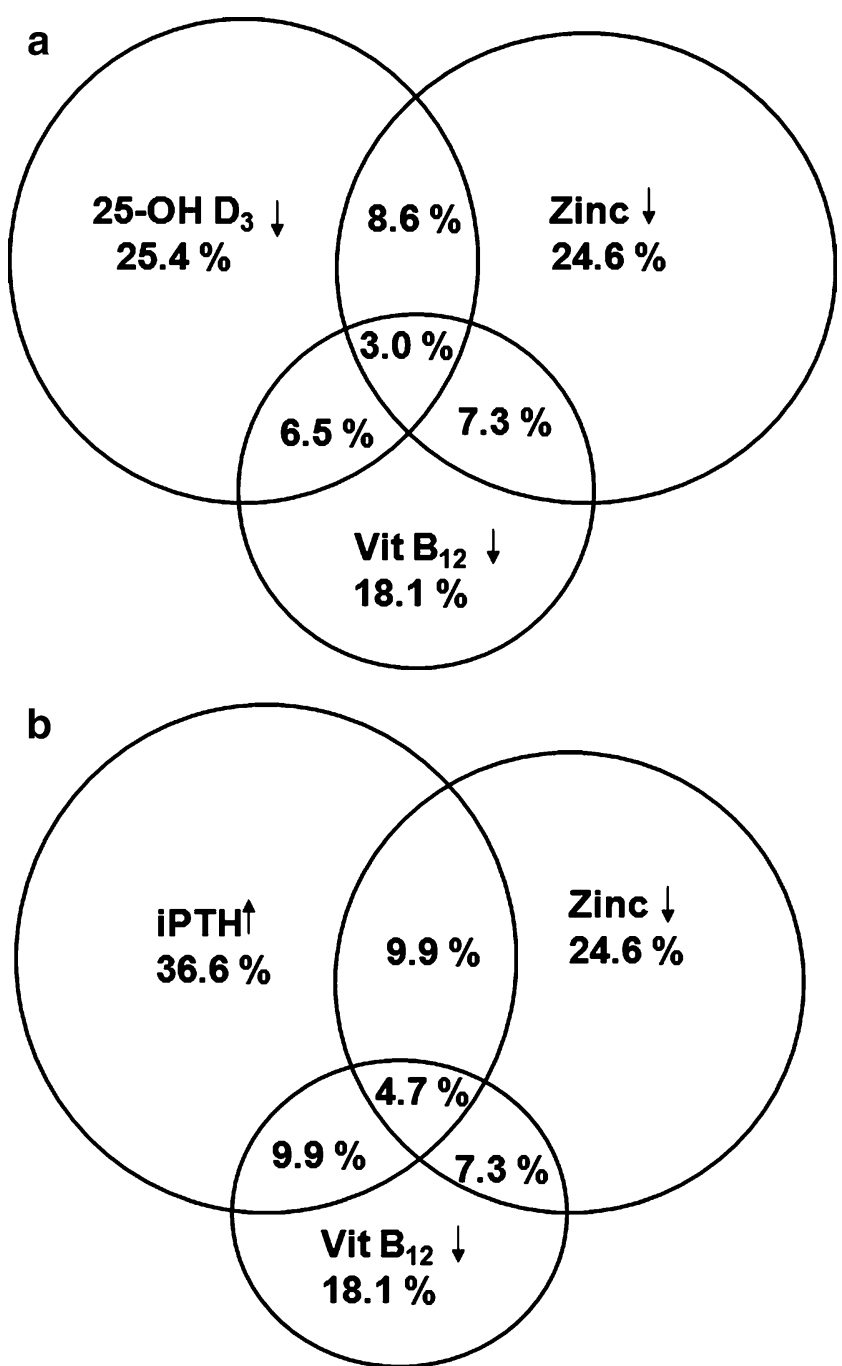

Fig. 1 Relationship between zinc, vitamin $\mathrm{B}_{12}$, and $25-\mathrm{OH}$ vitamin $\mathrm{D}_{3}$ deficiency (a) and between zinc deficiency, vitamin $\mathrm{B}_{12}$ deficiency, and iPTH elevation (b)

showing at least one alteration in the three parameters was even higher reaching $56.9 \%$ (Fig. 1b). There was no significant difference in these prevalences across the four BMI groups $(p=0.390$ for the analysis including $25-\mathrm{OH}$ vitamin $\mathrm{D}_{3}$ and $p=0.801$ for analysis including $\mathrm{PTH}$ ).

Looking at absolute values, there was a clear-cut decrease in albumin levels with increasing BMI $(p<0.001)$. Total calcium levels were also reduced in the higher as compared to the lower BMI groups $(p=0.045)$, but this difference between groups disappeared when calcium levels were corrected for albumin levels $(p=0.113)$. Also, ferritin, hemoglobin, vitamin $\mathrm{B}_{12}$, and $25-\mathrm{OH}$ vitamin $\mathrm{D}_{3}$ levels appeared to decrease with increasing BMI but differences across BMI groups did not reach significance (all $p>0.14$ ). However, iPTH levels clearly increase with BMI $(p=0.046)$ and correlation analysis confirmed the positive association between iPTH levels and BMI ( $r=0.191 ; p=0.004)$.
Comparison of data between men and women (Table 4) revealed that, as expected, men were significantly taller and heavier than women (both $p<0.001$ ), but age and BMI was similar in both sexes (both $p>0.34$ ). Women displayed significant lower albumin $(P=0.001)$, ferritin $(p<0.001)$, hemoglobin $(p<0.001)$, and zinc $(p=0.003)$ concentrations than men. Also, prevalence of ferritin deficiency was higher in women than in men $(p<0.038)$.

Table 5 provides data on serum copper, selenium, vitamin $B_{1}$, vitamin $B_{3}$, vitamin $B_{6}$, vitamin $A$, and vitamin E levels measured in a subgroup of 89 subjects. Here, $32.6 \%$ of the subjects showed a selenium deficiency, $5.6 \%$ a vitamin $\mathrm{B}_{3}$ deficiency, $2.2 \%$ a vitamin $\mathrm{B}_{6}$ deficiency, and $2.2 \%$ a vitamin $\mathrm{E}$ deficiency, while below cut-off levels were not found for copper, vitamin $\mathrm{B}_{1}$, and vitamin $\mathrm{A}$ in any of the subjects. Mean values for vitamin $\mathrm{B}_{1}(p=0.011)$ and vitamin A $(p=0.033)$ were significantly lower in women than in men, while that of copper were significantly higher in women $(p<0.001)$.

\section{Discussion}

Present data indicate a high prevalence $(>10 \%)$ of albumin, zinc, selenium, vitamin $\mathrm{B}_{12}$, and $25-\mathrm{OH}$ vitamin $\mathrm{D}_{3}$ deficiency as well as elevated iPTH levels in morbidly obese patients (BMI $\geq 35 \mathrm{~kg} / \mathrm{m}^{2}$ ). In addition, moderate rates of deficiencies (prevalence 5 to $10 \%$ ) were found for phosphate, ferritin, hemoglobin, and vitamin $\mathrm{B}_{3}$, and low prevalence rates $(<5 \%)$ of deficiencies were found for magnesium, vitamin $\mathrm{B}_{6}$, folate, and vitamin $\mathrm{E}$ levels. None of our patients showed deficiencies in serum levels of copper, vitamin $B_{1}$, and vitamin A. Rates of albumin deficiency and anemia (in women only) increased with BMI as did absolute iPTH levels. However, even a substantial number of the patients within the lowest BMI group $\left(35-40 \mathrm{~kg} / \mathrm{m}^{2}\right)$ displayed a micronutrient deficiency that should not be neglected.

Beside its obvious clinical significance in regard of the management of bariatric candidates, the present finding of a high prevalence rate of deficiency in distinct micronutrient components may also provide broader implications. Here, it is tempting to speculate that at least some of the found micronutrient deficiencies contribute to the well-known health impairing effects of obesity. For instance, vitamin D deficiency has been found to be associated with an increased risk for diabetes, cardiovascular diseases, and several types of cancer [23, 24]. Also, zinc deficiency is currently suggested to critically promote acute and chronic liver diseases [25] as well as the development of several types of cancer [26, 27]. To sum up, the high rate of micronutrient deficiencies found here strongly calls for further investigations assessing its potential contribution to the genesis of diseases being associated with obesity. 
Table 4 Comparison of absolute values of and deficiencies in micronutrients between men and women

\begin{tabular}{|c|c|c|c|}
\hline & Men $(n=67)$ & Women $(n=165)$ & $P$ value \\
\hline Age (year) & $41.4 \pm 11.4$ & $40.1 \pm 11.7$ & 0.436 \\
\hline Height $(\mathrm{cm})$ & $174.6 \pm 7.3$ & $162.8 \pm 6.7$ & $<0.001$ \\
\hline Weight (kg) & $138.8 \pm 19.6$ & $118.5 \pm 18.2$ & $<0.001$ \\
\hline BMI $\left(\mathrm{kg} / \mathrm{m}^{2}\right)$ & $45.5 \pm 5.3$ & $44.7 \pm 6.5$ & 0.342 \\
\hline Albumin $(\mu \mathrm{mol} / 1)$ & $634.7 \pm 66.7$ & $604.2 \pm 62.3$ & 0.001 \\
\hline Albumin $<536.0 \mu \mathrm{mol} / 1$ & $6.0 \%$ & $25.0 \%$ & 0.055 \\
\hline Phosphate $(\mathrm{mmol} / \mathrm{l})^{\mathrm{a}}$ & $1.0 \pm 0.2$ & $1.0 \pm 0.2$ & 0.666 \\
\hline Phosphate $<0.8 \mathrm{mmol} / \mathrm{l}^{\mathrm{a}}$ & $10.8 \%$ & $6.9 \%$ & 0.336 \\
\hline Magnesium $(\mathrm{mmol} / \mathrm{l})^{\mathrm{b}}$ & $0.9 \pm 0.2$ & $0.9 \pm 0.1$ & 0.152 \\
\hline Magnesium $<0.7 \mathrm{mmol} / \mathrm{l}^{\mathrm{b}}$ & $4.9 \%$ & $4.6 \%$ & 0.922 \\
\hline Ferritin $(\mathrm{pmol} / \mathrm{l})$ & $310.5 \pm 204.0$ & $106.2 \pm 94.4$ & $<0.001$ \\
\hline Ferritin $<18.0 \mathrm{pmol} / 1$ & $1.5 \%$ & $9.1 \%$ & 0.038 \\
\hline Hemoglobin $(\mathrm{mmol} / \mathrm{l})$ & $9.6 \pm 0.9$ & $8.6 \pm 0.7$ & $<0.001$ \\
\hline Hemoglobin $<8.7 \mathrm{mmol} / 1,<7.5 \mathrm{mmol} / \mathrm{l}^{\mathrm{c}}$ & 10.1 & 5.9 & 0.140 \\
\hline $\operatorname{Zinc}(\mu \mathrm{mol} / 1)$ & $12.8 \pm 2.0$ & $12.0 \pm 1.7$ & 0.003 \\
\hline Zinc $<11.0 \mu \mathrm{mol} / 1$ & $20.9 \%$ & $26.1 \%$ & 0.408 \\
\hline Folate $(\mathrm{nmol} / \mathrm{l})$ & $12.9 \pm 7.0$ & $13.1 \pm 9.1$ & 0.893 \\
\hline Folate $<4.5 \mathrm{nmol} / 1$ & $4.5 \%$ & $3.0 \%$ & 0.584 \\
\hline Vitamin $\mathrm{B}_{12}(\mathrm{pmol} / \mathrm{l})$ & $212.8 \pm 81.1$ & $197.8 \pm 82.1$ & 0.205 \\
\hline Vitamin $\mathrm{B}_{12}<133.0 \mathrm{pmol} / 1$ & $14.9 \%$ & $19.4 \%$ & 0.423 \\
\hline $25-\mathrm{OH}-\mathrm{D}_{3}(\mathrm{nmol} / \mathrm{l})$ & $44.3 \pm 25.2$ & $48.1 \pm 40.1$ & 0.391 \\
\hline $25-\mathrm{OH}-\mathrm{D}_{3}<76.0 \mathrm{nmol} / 1$ & $88.1 \%$ & $90.3 \%$ & 0.611 \\
\hline $25-\mathrm{OH}-\mathrm{D}_{3}<50.0 \mathrm{nmol} / 1$ & $62.7 \%$ & $60.6 \%$ & 0.768 \\
\hline $25-\mathrm{OH}-\mathrm{D}_{3}<25.0 \mathrm{nmol} / 1$ & $28.4 \%$ & $24.2 \%$ & 0.514 \\
\hline iPTH $(\mathrm{pmol} / \mathrm{l})$ & $6.1 \pm 2.3$ & $6.3 \pm 3.2$ & 0.514 \\
\hline $\mathrm{iPTH}>6.5 \mathrm{pmol} / 1$ & $35.8 \%$ & $37.0 \%$ & 0.869 \\
\hline
\end{tabular}

Data are the mean $\pm \mathrm{SD}$, or percentage. $P$ values derive from $\chi^{2}$ or unpaired Student's $t$ test as appropriate.

${ }^{a}$ Measured in 224 patients.

${ }^{\mathrm{b}}$ Measured in 213 patients.

${ }^{\mathrm{c}}$ Hemoglobin $<8.7 \mathrm{mmol} / 1$ for men and $<7.5 \mathrm{mmol} / \mathrm{l}$ for women.

Table 5 Absolute values and prevalence of deficiency in micronutrients measured only in a sub-sample of the study population

\begin{tabular}{|c|c|c|c|c|}
\hline & Total $(n=89)$ & Men $(n=23)$ & Women $(n=66)$ & $P$ value \\
\hline Age (year) & $40.7 \pm 10.7$ & $41.3 \pm 8.3$ & $40.5 \pm 11.5$ & 0.719 \\
\hline Height $(\mathrm{cm})$ & $166.3 \pm 8.1$ & $174.1 \pm 7.8$ & $163.6 \pm 6.4$ & $<0.001$ \\
\hline Weight (kg) & $121.2 \pm 21.7$ & $138.9 \pm 20.6$ & $115.0 \pm 18.6$ & $<0.001$ \\
\hline BMI $\left(\mathrm{kg} / \mathrm{m}^{2}\right)$ & $43.8 \pm 6.8$ & $45.8 \pm 5.7$ & $43.0 \pm 7.1$ & 0.068 \\
\hline Copper $(\mu \mathrm{mol} / \mathrm{l})$ & $20.0 \pm 4.8$ & $17.3 \pm 2.3$ & $21.0 \pm 5.0$ & $<0.001$ \\
\hline Copper $<13.0 \mu \mathrm{mol} / 1$ & $0 \%$ & $0 \%$ & $0 \%$ & - \\
\hline Selenium $(\mu \mathrm{mol} / \mathrm{l})$ & $1.1 \pm 0.2$ & $1.0 \pm 0.2$ & $1.1 \pm 0.2$ & 0.286 \\
\hline Selenium $<0.9 \mu \mathrm{mol} / 1$ & $32.6 \%$ & $39.1 \%$ & $30.3 \%$ & 0.437 \\
\hline Vitamin $B_{1}(\mathrm{nmol} / \mathrm{l})$ & $2740 \pm 516.7$ & $2956.6 \pm 433.3$ & $2663.3 \pm 523.3$ & 0.011 \\
\hline Vitamin $B_{1}<933.0 \mathrm{nmol} / 1$ & $0 \%$ & $0 \%$ & $0 \%$ & - \\
\hline Vitamin $B_{3}(\mu \mathrm{mo} / \mathrm{l})$ & $155.1 \pm 78.8$ & $138.1 \pm 53.6$ & $160.8 \pm 85.3$ & 0.139 \\
\hline Vitamin $B_{3}<65.0 \mu \mathrm{mo} / 1$ & $5.6 \%$ & $4.3 \%$ & $6.1 \%$ & 0.759 \\
\hline Vitamin $B_{6}(\mathrm{nmol} / \mathrm{l})$ & $74.1 \pm 37.0$ & $80.2 \pm 45.4$ & $72.1 \pm 34.0$ & 0.458 \\
\hline Vitamin $\mathrm{B}_{6}<33.2 \mathrm{nmol} / 1$ & $2.2 \%$ & $0 \%$ & $3.0 \%$ & 0.398 \\
\hline Vitamin A $(\mu \mathrm{mol} / \mathrm{l})$ & $3.3 \pm 1.0$ & $3.7 \pm 0.8$ & $3.2 \pm 1.0$ & 0.033 \\
\hline Vitamin $\mathrm{A}<0.7 \mu \mathrm{mol} / 1$ & $0 \%$ & $0 \%$ & $0 \%$ & - \\
\hline Vitamin E $(\mu \mathrm{mo} / \mathrm{l})$ & $36.0 \pm 10.7$ & $35.1 \pm 10.2$ & $36.2 \pm 11.2$ & 0.689 \\
\hline Vitamin $\mathrm{E}<12.0 \mu \mathrm{mo} / 1$ & $2.2 \%$ & $0 \%$ & $3.0 \%$ & 0.398 \\
\hline
\end{tabular}

Data are the mean $\pm \mathrm{SD}$, or percentage. $P$ values derive from $\chi^{2}$ or unpaired Student's $t$ test as appropriate. 
Several limitations of our study need to be pointed out. First, our study population was recruited from patients referred to our Interdisciplinary Obesity Center for obesity treatment. Therefore, results obtained here should not be generalized to a population-based level. Second, deficiency in micronutrient components may depend on cultural and geographical factors, and thus, our findings cannot be generalized to other cultures and geographical regions. For instance, vitamin $D_{3}$ production within the skin largely depends on the amount of sunlight exposure, making vitamin $\mathrm{D}_{3}$ deficiency more likely to occur in countries with rare sunshine or cultural limitations to expose large areas of uncovered skin to the sun. Also, the high number of selenium deficiencies found in our study most likely results from the fact that in the region of the Alps, soils were washed out during the glacial period [28]. Lastly, since we did not systematically assess micronutrient intake in the present study, it remains unclear whether the observed micronutrient deficiencies result from an inadequate intake by nutritional habits or other factors that have not been assessed here.

In conclusion, the present results clearly point to a rather high prevalence of micronutrient deficiencies in morbidly obese patients seeking obesity treatment. Although the clinical significance of most of these deficiencies remains to be established, based on the present data, we strongly recommend performing a systematically assessment of micronutrient status including at a minimum the determination of albumin, phosphate, ferritin, zinc, selenium, vitamin $\mathrm{B}_{12}, 25-\mathrm{OH}$ vitamin $\mathrm{D}_{3}, \mathrm{PTH}$, and vitamin $\mathrm{B}_{3}$ in candidates for bariatric surgery. Without such an assessment, it will be impossible to straightforwardly attribute micronutrient deficiencies that are detected after the operation to the bariatric procedure per se. Also, it can be assumed that starting a supplementation in regard of detected deficiencies prior to the bariatric operations yields beneficial effects.

\section{References}

1. Buchwald H, Avidor Y, Braunwald E, et al. Bariatric surgery: a systematic review and meta-analysis. JAMA. 2004;292:1724-37.

2. Maggard MA, Shugarman LR, Suttorp M, et al. Meta-analysis: surgical treatment of obesity. Ann Intern Med. 2005;142:547-59.

3. Karlsson J, Taft C, Ryden A, Sjostrom L, Sullivan M. Ten-year trends in health-related quality of life after surgical and conventional treatment for severe obesity: the SOS intervention study. Int J Obes (Lond). 2007;31:1248-61.

4. Sjostrom L, Narbro K, Sjostrom CD, et al. Effects of bariatric surgery on mortality in Swedish obese subjects. N Engl J Med. 2007;357:741-52.

5. Adams TD, Gress RE, Smith SC, et al. Long-term mortality after gastric bypass surgery. N Engl J Med. 2007;357:753-61.
6. Fujioka K. Follow-up of nutritional and metabolic problems after bariatric surgery. Diabetes Care. 2005;28:481-4.

7. Malinowski SS. Nutritional and metabolic complications of bariatric surgery. Am J Med Sci. 2006;331:219-25.

8. Westerterp-Plantenga MS, Wijckmans-Duijsens NE, Verboeketvan de Venne WP, de GK, van het Hof KH, Weststrate JA. Energy intake and body weight effects of six months reduced or full fat diets, as a function of dietary restraint. Int J Obes Relat Metab Disord. 1998;22:14-22.

9. Kimmons JE, Blanck HM, Tohill BC, Zhang J, Khan LK. Associations between body mass index and the prevalence of low micronutrient levels among US adults. MedGenMed. 2006;8:59.

10. Juhasz-Pocsine K, Rudnicki SA, Archer RL, Harik SI. Neurologic complications of gastric bypass surgery for morbid obesity. Neurology. 2007;68:1843-50.

11. Angstadt JD, Bodziner RA. Peripheral polyneuropathy from thiamine deficiency following laparoscopic Roux-en-Y gastric bypass. Obes Surg. 2005;15:890-2.

12. Chaves LC, Faintuch J, Kahwage S, Alencar FA. A cluster of polyneuropathy and Wernicke-Korsakoff syndrome in a bariatric unit. Obes Surg. 2002;12:328-34.

13. Bloomberg RD, Fleishman A, Nalle JE, Herron DM, Kini S. Nutritional deficiencies following bariatric surgery: what have we learned? Obes Surg. 2005;15:145-54.

14. Boylan LM, Sugerman HJ, Driskell JA. Vitamin E, vitamin B-6, vitamin B-12, and folate status of gastric bypass surgery patients. J Am Diet Assoc. 1988;88:579-85.

15. Turkki PR, Ingerman L, Schroeder LA, Chung RS, Chen M, Dearlove J. Plasma pyridoxal phosphate as indicator of vitamin B6 status in morbidly obese women after gastric restriction surgery. Nutrition. 1989;5:229-35.

16. Malinowski SS. Nutritional and metabolic complications of bariatric surgery. Am J Med Sci. 2006;331:219-25.

17. Rogers EL, Douglass W, Russell RM, Bushman L, Hubbard TB, Iber FL. Deficiency of fat soluble vitamins after jejunoileal bypass surgery for morbid obesity. Am J Clin Nutr. 1980;33:1208-14.

18. Primavera A, Brusa G, Novello P, et al. Wernicke-Korsakoff encephalopathy following biliopancreatic diversion. Obes Surg. 1993;3:175-7.

19. Nautiyal A, Singh S, Alaimo DJ. Wernicke encephalopathy-an emerging trend after bariatric surgery. Am J Med. 2004;117: $804-5$.

20. Loh Y, Watson WD, Verma A, Chang ST, Stocker DJ, Labutta RJ. Acute Wernicke's encephalopathy following bariatric surgery: clinical course and MRI correlation. Obes Surg. 2004;14:129-32.

21. Escalona A, Perez G, Leon F, et al. Wernicke's encephalopathy after Roux-en-Y gastric bypass. Obes Surg. 2004;14:1135-7.

22. Madan AK, Orth WS, Tichansky DS, Ternovits CA. Vitamin and trace mineral levels after laparoscopic gastric bypass. Obes Surg. 2006;16:603-6.

23. Holick MF. Vitamin D deficiency. N Engl J Med. 2007;357:266-81.

24. Bischoff-Ferrari HA, Giovannucci E, Willett WC, Dietrich T, wson-Hughes B. Estimation of optimal serum concentrations of 25-hydroxyvitamin D for multiple health outcomes. Am J Clin Nutr. 2006;84:18-28.

25. Stamoulis I, Kouraklis G, Theocharis S. Zinc and the liver: an active interaction. Dig Dis Sci. 2007;52:1595-612.

26. Chakravarty PK, Ghosh A, Chowdhury JR. Zinc in human malignancies. Neoplasma. 1986;33:85-90.

27. Guy NC, Garewal H, Holubec H, et al. A novel dietary-related model of esophagitis and Barrett's esophagus, a premalignant lesion. Nutr Cancer. 2007;59:217-27.

28. Sager M. Vertical mobility of selenium, arsenic and sulfur in model soil columns. Die Bodenkultur. 2008;53:83-103. 
29. Madan AK, Orth WS, Tichansky DS, Ternovits CA. Vitamin and trace mineral levels after laparoscopic gastric bypass. Obes Surg. 2006;16:603-6.

30. Skroubis G, Sakellaropoulos G, Pouggouras K, Mead N, Nikiforidis G, Kalfarentzos F. Comparison of nutritional deficiencies after Roux-en-Y gastric bypass and after biliopancreatic diversion with Roux-en-Y gastric bypass. Obes Surg. 2002; 12:551-8.

31. Brolin RE, Bradley LJ, Taliwal RV. Unsuspected cirrhosis discovered during elective obesity operations. Arch Surg. 1998;133:84-8.

32. Flancbaum L, Belsley S, Drake V, Colarusso T, Tayler E. Preoperative nutritional status of patients undergoing Roux-en-Y gastric bypass for morbid obesity. J Gastrointest Surg. 2006;10: 1033-7.

33. Madan AK, Orth WS, Tichansky DS, Ternovits CA. Vitamin and trace mineral levels after laparoscopic gastric bypass. Obes Surg. 2006;16:603-6.

34. Skroubis G, Sakellaropoulos G, Pouggouras K, Mead N, Nikiforidis G, Kalfarentzos F. Comparison of nutritional deficiencies after Roux-en-Y gastric bypass and after biliopancreatic diversion with Roux-en-Y gastric bypass. Obes Surg. 2002; 12:551-8.

35. Brolin RE, Bradley LJ, Taliwal RV. Unsuspected cirrhosis discovered during elective obesity operations. Arch Surg. 1998;133:84-8. 